\title{
Leader-member exchange fosters work engagement: The mediating role of job crafting
}

\begin{tabular}{|c|c|}
\hline \multicolumn{2}{|c|}{$\begin{array}{l}\text { Authors: } \\
\text { Mirjam Radstaak } \\
\text { Ayla Hennes }^{1,2}\end{array}$} \\
\hline \multicolumn{2}{|c|}{$\begin{array}{l}\text { Affiliations: } \\
{ }^{1} \text { Department of Psychology, } \\
\text { Health and Technology, } \\
\text { University of Twente, } \\
\text { Netherlands }\end{array}$} \\
\hline \multicolumn{2}{|c|}{$\begin{array}{l}{ }^{2} \text { Department of Psychology, } \\
\text { Utrecht University, } \\
\text { Netherlands }\end{array}$} \\
\hline \multicolumn{2}{|c|}{$\begin{array}{l}\text { Corresponding author: } \\
\text { Mirjam Radstaak, } \\
\text { m.radstaak@utwente.nl }\end{array}$} \\
\hline \multicolumn{2}{|c|}{$\begin{array}{l}\text { Dates: } \\
\text { Received: } 01 \text { May } 2017 \\
\text { Accepted: } 28 \text { July } 2017 \\
\text { Published: } 28 \text { Sept. } 2017\end{array}$} \\
\hline \multicolumn{2}{|c|}{$\begin{array}{l}\text { How to cite this article: } \\
\text { Radstaak, M., \& Hennes, A. } \\
\text { (2017). Leader-member } \\
\text { exchange fosters work } \\
\text { engagement: The mediating } \\
\text { role of job crafting. SA } \\
\text { Journal of Industrial } \\
\text { Psychology/SA Tydskrif vir } \\
\text { Bedryfsielkunde, 43(0), } \\
\text { a1458. https://doi. } \\
\text { org/10.4102/sajip.v43. } \\
\text { i0.1458 }\end{array}$} \\
\hline \multicolumn{2}{|c|}{$\begin{array}{l}\text { Copyright: } \\
\text { (C) 2017. The Authors. } \\
\text { Licensee: AOSIS. This work } \\
\text { is licensed under the } \\
\text { Creative Commons } \\
\text { Attribution License. }\end{array}$} \\
\hline \multicolumn{2}{|l|}{ Read online: } \\
\hline 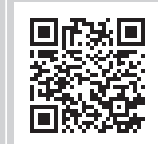 & $\begin{array}{l}\text { Scan this QR } \\
\text { code with your } \\
\text { smart phone or } \\
\text { mobile device } \\
\text { to read online. }\end{array}$ \\
\hline
\end{tabular}

Orientation: The right balance between job demands and job resources are essential for employees to bring energy and enthusiasm to work. Employees who experience high-quality relationships with their supervisors may actively craft their job demands and job resources and feel more engaged.

Research purpose: The current study examined the associations between leader-member exchange (LMX), job crafting and work engagement.

Motivation: This study attempts to gain more insight in the associations between LMX, job crafting and work engagement. It was hypothesised that high-quality relationships with supervisors fosters work engagement because it stimulates employees to craft their jobs by increasing social and structural job resources and challenging job demands and by decreasing hindering job demands.

Research approach, design and methodology: Participants $(N=402)$ working for a leading mail and parcels company in the Netherlands completed questionnaires measuring LMX, work engagement and job crafting. Structural equation modelling was used to examine the hypotheses.

Main findings: Increasing social job resources $(\beta=0.01, \mathrm{SE}=0.00, p<0.001)$ and increasing challenging job demands $(\beta=0.08, \mathrm{SE}=0.04, p<0.05)$ were significant mediators in the association between LMX and work engagement. Increasing structural job resources $(\beta=0.00$, $\mathrm{SE}=0.00, p=0.92)$ and decreasing hindering job demands $(\beta=-0.00, \mathrm{SE} 0.00, p=0.09)$ were not significant mediators.

Practical and managerial implications: Supervisors who are capable of building high-quality relationships with their employees based on trust, respect and loyalty will foster a positive, fulfilling work-related state of mind among employees because they are more willing to proactively craft a challenging and resourceful work environment.

Contribution or value-add: The findings of this study showed the importance of high-quality relationships with supervisors and were unique in examining the association between LMX and job crafting.

\section{Introduction}

Organisations are under tremendous pressures to survive and progress in a continuously changing world of work (Ndlouvu \& Parumasur, 2005). In this competitive work environment, the quality of human resources is of vital importance to achieve organisational success (Macey \& Schneider, 2008). Engaged employees are willing to invest more than is expected (Babcock-Roberson \& Strickland, 2010), are more productive (Harter, Schmidt \& Hayes, 2002), perform better (Allesandri, Borgogni, Schaufeli, Caprara \& Consiglio, 2015) and show less sickness absenteeism (Schaufeli, Bakker \& van Rhenen, 2009). Not only these practical reasons make it important for managers and researchers to be concerned about work engagement, there are humanistic reasons as well (May, Gilson \& Harter, 2004). Engaged employees are more satisfied with their jobs (Giallonardo, Wong \& Iwasiw, 2010), enjoy good health (Seppäla et al., 2012), positive work affect (Sonnentag, Mojza, Binnewies \& Scholl, 2008) and experience more well-being at work (Rothmann, 2008).

Increasing employee engagement is a challenging and complex undertaking. Some researchers have suggested that the quality of the relationship between supervisors and employees, also known as the leader-member exchange (LMX; Graen \& Uhl-Bien, 1995), plays a pivotal role in fostering work engagement (Macey \& Schneider, 2008). The principle of LMX theory is that supervisors develop different types of exchange relationships with their employees (Bauer \& Green, 1996). The quality of these relationships influences important leader and member 
attitudes and behaviours (Bhal, Gulati \& Ansari, 2009; Gerstner \& Day, 1997; Sparrowe \& Liden, 1997). Few studies have examined the positive association between LMX and work engagement (Agarwal, Datta, Blake-Beard \& Bhargava, 2012; Breevaart, Bakker, Demerouti \& van den Heuvel, 2015; Li, Sanders \& Frenkel, 2012). The only study that examined the mechanisms that lie beyond this association showed that a resourceful work environment provided in a high-quality LMX increased work engagement among the employees (Breevaart et al., 2015).

Unfortunately, supervisors are not always available to support their employees, and the fast-changing competitive work environment may set other priorities for them (Bakker, Tims \& Derks, 2012). Under such conditions, it may be particularly important for employees to mobilise their own job resources to stay engaged. Pro-active work behaviours aimed at improving person-job fit and work motivation by altering job demands and job resources have been defined as job crafting (Tims, Bakker \& Derks, 2012). We assume that LMX increases work engagement not only through the creation of a resourceful work environment by supervisors but also because employees are more motivated to craft job demands and resources in accordance to their needs. This study is unique in examining the association between LMX and job crafting behaviours and proposes that a high-quality relationship with supervisors foster work engagement through pro-active job crafting behaviours. It adds to the body of research examining the importance of job demands and job resources in relation to work engagement (Demerouti \& Bakker, 2011) and adds new knowledge to the field by emphasising the importance of job crafting behaviours in the association between LMX and work engagement.

\section{Literature review}

\section{Work engagement}

Kahn (1990) introduced the concept of engagement. He proposed that personal engagement represents a state in which employees 'bring in' their personal selves and are fully physically, cognitively and emotionally connected with their work roles. This means that work engagement is fundamentally a motivational concept that represents the active allocation of personal resources towards the different work tasks (Kanfer, 1990; Rich, LePine \& Crawford, 2010). Two characteristics are noteworthy in Kahn's (1990) conceptualisation of work engagement. Firstly, work engagements should refer to the employees' experience during the performance of work tasks rather than the attitude towards work conditions. Secondly, work engagement involves the investment of personal resources in work (Christian, Garza \& Slaughter, 2011). A conceptualisation of work engagement that includes both the employees' experience and the investment of personal resources is the definition proposed by Schaufeli, Salanova, González-Romá and Bakker (2002). They defined work engagement as a positive, fulfilling, work-related state of mind that is characterised by vigour, dedication and absorption. Vigour refers to high levels of energy and mental resilience while working and the willingness to invest effort and persist, even in the face of difficulties. Dedication means that one is enthusiastic, inspired, proud, challenged and strongly involved by work. Absorption is characterised by being fully attentive, engaged and concentrated in one's work, whereby time passes quickly (Bakker, Schaufeli, Leiter \& Taris, 2008).

The importance of job demands and job resources in work engagement has been emphasised by the Job DemandsResources model (JD-R; Bakker \& Demerouti, 2007; Demerouti \& Bakker, 2011; Demerouti, Bakker, Nachreiner \& Schaufeli, 2001). This model categorises job characteristics into two general categories: (1) job demands and (2) job resources. Job demands refer to the physical, social or organisational aspects of the job that require sustained mental or physical effort and deplete psychological or physiological resources. Job resources are the physical, psychological social or organisational aspects of the job that are functional in achieving goals, reduce job demands and stimulate personal growth and development (Bakker \& Demerouti, 2007; Demerouti \& Bakker, 2011; Demerouti et al., 2001). The JD-R model assumes two psychological processes that are important in the development of job-related strain and motivation: (1) a process of health impairment in which high job demands exhaust employees' mental and physical resources, which may lead to a depletion of energy resources and strain and (2) a motivational process in which high job resources foster work engagement by playing an intrinsic motivational role, fulfilling human needs, or an extrinsic motivational role, through successful task completion and satisfaction (Demerouti \& Bakker, 2011).

Numerous studies in various occupations and countries show that job demands are related to strain and job resources to work engagement (for a meta-analysis, see Crawford, LePine \& Rich, 2010). A study among teachers in African countries revealed that job resources such as autonomy and feedback were positively related to work engagement (Fouché, Rothmann \& van der Vyver, 2017) even though teachers in African countries are facing poor job conditions and high job demands (Jackson, Rothmann \& Van de Vijver, 2006; Willemse \& Deacon, 2015). Longitudinal research also supports the positive effect of job resources on work engagement. A study among Finnish healthcare personnel revealed that higher levels of job control in 2003 were associated with higher levels of vigour, dedication, and absorption in 2005 (Mauno, Kinnunnen \& Ruokolainen, 2007), especially job resources such as autonomy and feedback have been associated with work engagement. These job resources correlated more strongly with work engagement than did job demands such as physical demands and job complexity (for a meta-analysis, see Christian et al., 2011). For example, vigour and dedication among managers working for a platinum mine in Africa was predicted by organisational support, and not workload (Rothmann \& Joubert, 2007).

\section{Leader-member exchange}

The quality of relationships between supervisors and employees, often studied via the leader-member exchange 
theory (LMX; Graen \& Uhl-Bien, 1995), is another antecedent that fosters employees' work engagement (Macey \& Schneider, 2008). A central principle of LMX theory is that supervisors form differential relationships with their subordinates that range on a continuum from lower to higher quality exchanges (Bauer \& Green, 1996). This relationship evolves and grows over time as supervisors and employees learn more about each other and have new and different experiences (Gerstner \& Day, 1997; Liden, Wayne \& Stilwell, 1993). Low-quality relationships with supervisors are characterised by economic exchanges, mistrust, low respect, and a lack of loyalty. High-quality relationships are based on trust, respect, obligation and loyalty (Graen \& Uhl-Bien, 1995; Morrow, Suzuki, Crum, Ruben \& Pautsch, 2005). Employees and organisations benefit from relationships between supervisors and employees that evolve into highquality LMX. High-quality LMX has been associated with increased citizenship behaviours, performance, creativity, job satisfaction, commitment and decreased turnover intentions (Dulebohn, Bommer, Liden, Brouer \& Ferris, 2012; Gerstner \& Day, 1997; Ilies, Nahrgang \& Morgeson, 2007; Martin, Guillaume, Thomas, Lee \& Epitropaki, 2016). In a study among Chinese supervisors and their employees, highquality LMX facilitated creative ideas among employees to improve performance (Gu, Tang \& Jiang, 2015).

High-quality LMX may also enhance employees' work engagement. Supervisors in high-quality LMX give their employees more of their time, more direct information, more emotional support, more intrinsic rewards such as empowerment and praise and more extrinsic rewards such as salary raise, which results in positive attitudes towards work and higher levels of work engagement (Epitropaki \& Martin, 2005; Jacobs, Renard \& Snelgar, 2014; Sparrowe \& Liden, 1997; Stander \& Rothmann, 2010). Moreover, employees in a high-quality LMX are found to be more optimistic and self-efficacious, and such self-beliefs are important predictors of work engagement (Halbesleben, 2010). The positive association between LMX and work engagement can also be explained by social exchange theory (SET; Nord, 1969). SET suggests that unspecified obligations are created by receiving favours in a state of reciprocal independence (Gouldner, 1960). In high-quality LMX, supervisors provide intangible and tangible resources to employees. In turn, employees feel motivated to work harder to benefit the supervisor as a means of reciprocation (Liden, Sparrowe \& Wayne, 1997) or could repay the received favours through engagement. Those employees might also feel more psychologically safe (Carmeli, Brueller \& Dutton, 2009). Psychological safety is the belief that the work environment is safe to take interpersonal risks (Edmondson, 1999; Kahn, 1990). When employees 'feel able to show and employ one's self without fear of negative consequences to self-image, status, or career' (Kahn, 1990, p. 708), they will take more risks to express their true selves and actively engage their interest in work tasks (May et al., 2004).

Few studies have examined the associations between LMX and work engagement. In studies among Indian managerial employees working in the service sector and Chinese luxury hotel employees, LMX was positively associated with a positive, fulfilling, work-related state of mind (Agarwal et al., 2012; Li et al., 2012). A study conducted among Dutch police officers examined the mechanisms beyond this association and revealed that high-quality LMX is associated with higher levels of work engagement through higher levels of available job resources, especially developmental opportunities and social support (Breevaart et al., 2015). However, supervisors might not always be available to give their employees the job resources that they need and employees may need to mobilise their own job resources to stay engaged. Nowadays it is widely acknowledged that employees are not passive receptacles of their work environment; instead, they actively change it (Wrzesniewski \& Dutton, 2001).

\section{Job crafting}

The central characteristic of job crafting is that employees take personal initiative to alter their tasks or other job characteristics (Tims et al., 2012). Wrzesniewski and Dutton (2001) introduced the term 'job crafting' to capture the physical, cognitive and relational actions employees take to shape, mould and redefine their jobs. Job crafting is a specific form of pro-active behaviour because it is primarily aimed at improving person-job fit and work motivation by taking a self-starting approach. It focuses on how employees alter their job designs in accordance with their own preferences, values and skills (Tims et al., 2012). Job crafting is often framed in the JD-R model (Bakker \& Demerouti, 2007; Demerouti et al., 2001; Demerouti \& Bakker, 2011). In this context, job crafting behaviours are the changes that employees make to balance their job demands and job resources with their personal abilities and needs (Tims \& Bakker, 2010). Past research has distinguished four different dimensions of job crafting: (1) increasing social job resources reflects the mobilising of feedback and advice from colleagues and supervisors, (2) increasing structural job resources reflects the professional development of the employee, (3) increasing challenging job demands reflects the search for challenges and opportunities at work and (4) decreasing hindering job demands reflects employees avoiding emotional or mental job demands (Tims et al., 2012).

Research has shown that proactively changing job resources and job demands may improve person-job fit and increase work engagement (Bakker et al., 2012; Bakker, RodríguezMuñoz \& Sans Vergel, 2016; De Beer, Tims \& Bakker, 2016; Olivier \& Rothmann, 2007; Petrou, Demerouti, Peeters, Schaufeli \& Hetland, 2012; Tims, Bakker \& Derks, 2013). A recent study examining job crafting behaviours among African employees working in the mining sector showed that increasing challenging job demands and increasing social job resources were positively associated with work engagement (De Beer et al., 2016).

By seeking job resources, such as asking advice or asking feedback on one's performance, employees act proactively to 
gain specific resources. The basic tenet of the conservation of resources theory is that humans are motivated to protect their resources and acquire new resources (Hobfoll, 1989). Consequently, pro-active coping can have the goal to increase job resources, which has positive outcomes for employee motivation and engagement (Salanova \& Schaufeli, 2008). The beneficial effects of seeking job resources have been shown by a longitudinal study among Dutch employees. In this study, increasing job resources was associated with higher levels of work engagement 1 month later (Tims et al., 2013). Moreover, seeking resources can also be a way to mobilise more job resources to cope with job demands (Tims \& Bakker, 2010).

Increasing challenging job demands, such as looking for new tasks at work or taking on more responsibilities, stimulates employees to develop their knowledge and skills and to attain more difficult goals (LePine, Podsakoff \& LePine, 2005). The positive emotions and attitudes associated with task accomplishment and personal growth could enhance work engagement (Podsakoff, LePine \& LePine, 2007). Indeed, research showed that seeking challenges during the day was positively associated with daily changes in work engagement (Bakker et al., 2012).

Decreasing hindering job demands has been suggested as a possible 'negative' side of job crafting (Oldham \& Hackman, 2010; Wrzesniewski \& Dutton, 2001). Behaviours aimed at minimising the emotionally, mentally or physically demanding job aspects or reducing workload and time pressure are examples of reducing job demands. The costs experienced by addressing hindering demands may be a motive for employees to reduce them (Tims et al., 2012). However, by decreasing hindering job demands, employees will also reduce the triggers or necessity for action and the optimal level of job challenge may decrease (Csikszentmihalyi, 1990). This implies that reducing hindering job demands has no beneficial effect on work engagement or could even decrease work engagement. This was exactly the finding in a study among employees who underwent change at their work, such as new tasks or technical changes. When the employee decreased their job demands, their level of work engagement decreased too (Petrou et al., 2012).

\section{Research purpose and objectives}

This study will examine whether high-quality relationships with supervisors foster work engagement through pro-active job crafting behaviours and is unique in examining the association between LMX and job crafting. The literature reviewed suggests that employees in high-quality relationships with supervisors feel more psychologically safe (Carmeli et al., 2009; Edmondson, 1999; Kahn, 1990) and are motivated to repay the received favours by their supervisors (Gouldner, 1960; Liden et al., 1997; Nord, 1969). This may cause employees to be more motivated to craft their jobs and increase social and structural job resources and increase challenging job demands, which results in higher levels of work engagement (Bakker et al., 2012; Petrou et al., 2012; Tims et al., 2013). They may be less motivated to decrease hindering job demands, which is negatively associated with work engagement (Csikszentmihalyi, 1990; Petrou et al., 2012). The following hypotheses have been formulated:

H1: Increasing social job resources mediates the association between LMX and work engagement

H2: Increasing structural job resources mediates the association between LMX and work engagement

H3: Increasing challenging job demands mediates the association between LMX and work engagement

H4: Decreasing hindering job demands mediates the association between LMX and work engagement

\section{Research design}

\section{Research approach}

In this study, a quantitative cross-sectional research design was used to explore the associations among the variables. A quantitative design highlights the associations of factors at a given time within a specific population. However, no causal associations can be inferred (Pearl, 2009).

\section{Research method}

\section{Research participants}

Participants consisted of 402 employees working for a leading mail and parcels company in the Netherlands. About 1000 employees were approached for participation (response rate $\pm 40 \%$ ). The age of the participants ranged from 19 to 64 and the average age of the sample was $45.56(\mathrm{SD}=10.62)$ years. Of the sample, $70.4 \%$ were men and $29.6 \%$ were women. Most participants had a college or university degree (67.4\%). Participants worked in the Information and Communication Technology Department (30.3\%), the Financial Department $(27.6 \%)$, the Control and Strategy Department (11.4\%), the Real Estate and Facilities Department (10.2\%), the Human Resources Department (9.2\%) or in the 'Other' Department (11.3\%). Participants worked on average $6.03(\mathrm{SD}=13.14)$ years at their current job.

\section{Research procedure}

The study announcement, along with information assuring confidentially and voluntary participation, was distributed by the directors of the departments. Employees received an e-mail with a link to the online survey and were assured that their supervisors and organisation would not know their individual responses to the survey. It took participants $10 \mathrm{~min}-15 \mathrm{~min}$ to complete the survey. After participants completed the survey, they were fully debriefed about the purpose of the study, and the contact details of the researcher were provided for possible questions. The data were collected in April 2015.

\section{Measuring instruments}

Demographics: Gender, age, education level and years working for current supervisor were measured. 
Quality of relationship with supervisor: Quality of LMX was measured using a seven-item questionnaire based on the member versions of the LMX questionnaires (Liden \& Graen, 1980). Respondents indicated the extent to which the items characterised the quality of their exchange relationship with their supervisors. Items were rated on a seven-point Likert scale $(1=$ to a very low extent, $7=$ to a very high extent $)$. A sample item is: 'My supervisor would be personally inclined to help me solve problems in my work'.

Work engagement: Work engagement was measured with the nine-item version of the Utrecht Work Engagement Scale (UWES; Schaufeli, Bakker \& Salanova, 2006). The UWES reflects three underlying dimensions: (1) vigour ('At my work, I feel bursting with energy'), (2) dedication ('I find the work that I do full of meaning and purpose') and (3) absorption ('Time flies when I am working'). Items were rated on a seven-point Likert scale $(1=$ never, $7=$ always $)$.

Job crafting: The 21-item job crafting scale (Tims et al., 2012) was used to measure the self-initiated changes that employees make to balance their job demands and resources with their personal abilities and needs (Tims \& Bakker, 2010). The job crafting scale reflects four underlying dimensions: (1) increasing structural job resources (five items, e.g., 'I try to develop my capacities'), (2) decreasing hindering job demands (six items, e.g., 'I make sure that my work is mentally less intense'), (3) increasing social job resources (five items, e.g. 'I ask my supervisor to coach me') and (4) increasing challenging job demands (six items, e.g. 'When an interesting project comes along, I offer myself proactively as project co-worker'). Items were rated on a seven-point Likert scale $(1=$ never, $7=$ always $)$.

\section{Data analysis}

Structural equation modelling in Mplus 7.11 (Muthén \& Muthén, 2012) was used to test the hypothesised model, using the robust maximum likelihood estimation to correct for non-normality in the data. A good model fit was assessed with a non-significant $\chi^{2}$-test, a $\chi^{2} / \mathrm{df}$ ratio lower than 3:1 for satisfactory fit or below 2:1 indicating excellent fit, root mean square error of approximation (RMSEA) and standardised root mean square residual (SRMR) values less than 0.08 suggesting acceptable fit and values less than 0.05 suggesting good fit, and a comparative fit index (CFI) above 0.90 indicating acceptable fit and above 0.95 indicating good fit (Browne \& Cudeck, 1989; Hu \& Bentler, 1999; Kline, 2005; Marsh, Hau \& Wen, 2004).

To examine the hypothesised model, the two-step approach recommended by Anderson and Gerbing (1988) was followed. Firstly, confirmatory factor analyses (CFAs) were performed to examine the measurement model. Items with a factor loading $<0.4$ were omitted from the analyses (Stevens, 2002). In addition, the reliability of the questionnaires was determined using omega. Omega considers the differences in factor loadings and is therefore a better indicator of reliability than alpha (Dunn, Baguley \& Brunsden, 2014). When the measurement model had an acceptable model fit and the omegas were sufficient, the means and the correlations between the constructs and demographic variables were calculated using SPSS 23.0.

Secondly, the fit of the structural model was examined by adding the predicted direct and indirect associations between the latent factors. The job crafting scales were allowed to correlate. Age and education level were added as covariates to the structural model because we wanted to control for the effect of education level on LMX (Tims et al., 2012) and age on work engagement (Schaufeli et al., 2006).

\section{Results}

\section{Measurement model}

\section{Quality of relationship with supervisor}

The one-factor CFA revealed a good fit $\left(\chi^{2}[14]=21.08, p=0.10\right.$; $\chi^{2} /$ df ratio $=1.51 ;$ SRMR $=0.03 ;$ RMSEA $\left.=0.04, \mathrm{CFI}=0.99\right)$. However, the fourth item ('Regardless of how much formal authority he or she has built into his or her position, what are the chances that your leader would use his or her power to help you solve problems in your work?') had a factor loading $<0.4$ on the latent construct LMX. Therefore, this item was omitted from the analysis, which resulted in an excellent model fit $\left(\chi^{2}[9]=10.72, p=0.29 ; \chi^{2} / \mathrm{df}\right.$ ratio $=1.19 ; \mathrm{SRMR}=0.02$; RMSEA $=0.02, \mathrm{CFI}=1.00)$. The scale had a good reliability $(\omega=0.91)$.

\section{Work engagement}

The CFA with the three-factor model vigour, dedication and absorption and the higher order factor engagement had a better fit $\left(\chi^{2}[24]=94.93, p<0.001 ; \chi^{2} / \mathrm{df}\right.$ ratio $=3.96$; SRMR $=$ 0.05 ; RMSEA $=0.09, \mathrm{CFI}=0.94)$ than a one-factor solution $\left(\chi 2[27]=171.62, p<0.001 ; \chi^{2} / \mathrm{df}\right.$ ratio $=6.36 ;$ SRMR $=0.06$; $\mathrm{RMSEA}=0.12, \mathrm{CFI}=0.88)$. Item 6 'I am proud on the work that I do (dedication)' and item 8 'I am immersed in my work (absorption)' were independently related. Therefore, a residual correlation was added between these indicators resulting in an acceptable model fit $\left(\chi^{2}[23]=72.08, p<0.001\right.$; $\chi^{2} / \mathrm{df}$ ratio $=3.13 ;$ SRMR $=0.04 ;$ RMSEA $=0.07, \mathrm{CFI}=0.96$ ). The reliability of the scale was good (vigour: $\omega=0.78$; dedication: $\omega=0.89$, absorption: $\omega=0.77$; and work engagement: $\omega=0.91$ ).

\section{Job crafting}

The CFA revealed an acceptable fit for the four-factor solution $\left(\chi^{2}[182]=433.84, p<0.001 ; \chi^{2} / \mathrm{df}\right.$ ratio $=2.38 ;$ SMRS $=0.07$; RMSEA $=0.06, \mathrm{CFI}=0.88$ ). Four items had a factor loading $<0.4$ and were omitted from the analysis - item 4: 'I make sure that I use my capacities to the fullest' (increasing structural job resources); item 5: 'I decide on my own how I do things' (increasing structural job resources); item 16: 'I ask colleagues for advice' (increasing social job resources), and item 18: 'If there are new developments, I am one of the first to learn about them and try them out' (increasing challenging job demands) - which resulted in a good model fit $\left(\chi^{2}[113]=257.96, p<0.001 ; \chi^{2} /\right.$ df ratio $=1.42 ;$ SMRS $=0.06$; 
RMSEA $=0.06, C F I=0.92]$. The reliability of the scale was sufficient (increasing structural job resources: $\omega=0.79$; decreasing hindering job demands: $\omega=0.76$, increasing social job resources: $\omega=0.81$; and increasing challenging job demands: $\omega=0.73$ ).

Table 1 depicts descriptive statistics and zero-order correlations for all variables. Participants worked on average less than 4 years $(M=3.87)$ for their current supervisor and reported a high-quality LMX with their supervisors $(M=$ 5.76). Levels of work engagement were intermediate $(M=$ 5.16). Increasing structural job resources $(M=3.67)$ was the most frequently used strategy to change job characteristics and decreasing hindering job demands $(M=1.72)$ was the least used strategy.

\section{Structural model}

The result of the SEM analysis revealed an acceptable fit of the structural model to the data $\left(\chi^{2}[504]=1049.87, p<0.001 ; \chi^{2} / \mathrm{df}\right.$ ratio $=2.08$; SMRS $=0.08$; RMSEA $=0.05, \mathrm{CFI}=0.89)$. The explained variance was significant in all latent dependent variables (Increasing social job resources: $R^{2}=0.18, p<0.001$; Increasing structural job resources: $R^{2}=0.09, p<0.001$; Increasing challenging job demands: $R^{2}=0.13, p<0.001$; decreasing hindering job demands: $R^{2}=0.06, p=0.04$; Vigour: $R^{2}=0.79$, $p<0.001$; Dedication; $R^{2}=0.91, p<0.001$; Absorption : $R^{2}=0.67$, $p<0.001$; Work engagement: $\left.R^{2}=0.26, p<0.001\right)$. See Figure 1 for an overview of the structural model.

The direct effect between LMX and work engagement was significant $(\beta=0.02, \mathrm{SE}=0.00, p<0.001)$. Moreover, $\mathrm{LMX}$ was significantly associated with increasing social job resources $(\beta=0.32, \mathrm{SE}=0.05, p<0.001)$ and not associated with increasing structural job resources $\beta=0.01, \mathrm{SE}=0.06$, $p=0.92)$. LMX was positively associated with increasing challenging job demands $(\beta=0.16, \mathrm{SE}=0.07, p=0.02)$ and marginally significantly associated with decreasing hindering job demands $(\beta=-0.11, \mathrm{SE}=0.06, p=0.06)$. Increasing social job resources $(\beta=0.02, \mathrm{SE}=0.00, p=<0.001)$, increasing structural job resources $(\beta=0.01, \mathrm{SE}=0.00, p<0.001)$, increasing challenging job demands $(\beta=0.47, \mathrm{SE}=0.06$, $p<0.001)$ and decreasing hindering job demands $(\beta=0.01$, $\mathrm{SE}=0.00, p<0.001)$ were all positively associated with work engagement.
In support of hypothesis 1 , the analysis revealed a significant indirect effect between LMX, increasing social job resources and work engagement $(\beta=0.01, \mathrm{SE}=0.00, p<0.001)$. Hypothesis 2 was not supported because there was no significant indirect effect between LMX, increasing structural job resources and work engagement $(\beta=0.00, \mathrm{SE}=0.00$, $p=0.92)$. The significant indirect effect between LMX, increasing challenging job demands and work engagement $(\beta=0.08, \mathrm{SE}=0.04, p<0.05)$ was in support of hypothesis 3 . Hypothesis 4 was not supported because there was no significant indirect effect between LMX, decreasing hindering job demands and work engagement $(\beta=-0.00$, $\mathrm{SE}=0.00, p=0.09$ ).

\section{Discussion}

The current study examined the associations between LMX, work engagement and job crafting among employees working for a mail and parcels company. We expected that high-quality relationships with supervisors foster work engagement because it motivates employees to employ proactive job crafting behaviours.

\section{Outline of the results}

Our first hypothesis was supported because increasing social job resources was a significant mediator in the association between LMX and work engagement. Employees who reported a high-quality relationship with their supervisor were more inclined to craft social job resources, which made them feel more engaged in their work. This finding is consistent with the motivational process of the JD-R model in which job resources are positively related to work engagement (Demerouti \& Bakker, 2011). Although job crafting has been defined as the self-starting and pro-active approach to work and not the passive response to the work environment (Tims et al., 2012), we cannot exclude the possibility that employees were more inclined to craft their jobs because they had more available resources (Liden et al., 1997). Past research has shown that high-quality relationships with supervisors were associated with higher levels of job resources (Breevaart et al., 2015) and a longitudinal study revealed that the availability of job resources was predictive of job crafting behaviours 1 month later (Tims et al., 2013). Future research should measure job crafting behaviours and the presence of

TABLE 1: Descriptive statistics and correlations.

\begin{tabular}{|c|c|c|c|c|c|c|c|c|c|c|c|c|c|}
\hline Variables & $N$ & Mean & $\begin{array}{l}\text { Standard } \\
\text { deviation }\end{array}$ & 1 & 2 & 3 & 4 & 5 & 6 & 7 & 8 & 9 & 10 \\
\hline 1. Gender & 402 & - & - & - & - & - & - & - & - & - & - & - & - \\
\hline 2. Age & 394 & 45.56 & 10.62 & $0.24 * *$ & - & - & - & - & - & - & - & - & - \\
\hline 3. Education level & 402 & 4.59 & 1.35 & -0.07 & $-0.40 * *$ & - & - & - & - & - & - & - & - \\
\hline 4. Years working for supervisor & 394 & 3.87 & 6.19 & 0.06 & $0.26 * *$ & $-0.21 * *$ & - & - & - & - & - & - & - \\
\hline 5. Leader-member exchange & 402 & 5.76 & 0.89 & 0.02 & -0.03 & 0.03 & 0.05 & - & - & - & - & - & - \\
\hline 6. Work engagement & 402 & 5.16 & 0.92 & 0.03 & $0.11 *$ & $-0.11 *$ & -0.05 & $0.29 * *$ & - & - & - & - & - \\
\hline 7. Increasing social job resources & 402 & 2.54 & 0.83 & $-0.11 *$ & $-0.26 * *$ & $0.23 * *$ & -0.05 & $0.29 * *$ & $0.27 * *$ & - & - & - & - \\
\hline 8. Increasing structural job resources & 402 & 3.67 & 0.74 & 0.04 & -0.08 & $0.13 * *$ & -0.08 & -0.01 & $0.30 * *$ & $0.40 * *$ & - & - & - \\
\hline 9. Increasing challenging job demands & 402 & 3.08 & 0.78 & 0.04 & $-0.15 * *$ & $0.23 * *$ & $-0.13^{*}$ & $0.11 *$ & $0.36^{* *}$ & $0.47 * *$ & $0.52 * *$ & - & - \\
\hline 10. Decreasing hindering job demands & 402 & 1.72 & 0.50 & 0.01 & -0.08 & 0.01 & -0.01 & $-0.14 *$ & $-0.16 *$ & $0.15 *$ & 0.02 & -0.01 & - \\
\hline
\end{tabular}

Note: Spearman's rho was calculated to examine the association between gender and the other variables. Pearson's $r$ was calculated to examine the association between all other variables. $*, p<0.05 ; * *, p<0.001$. 


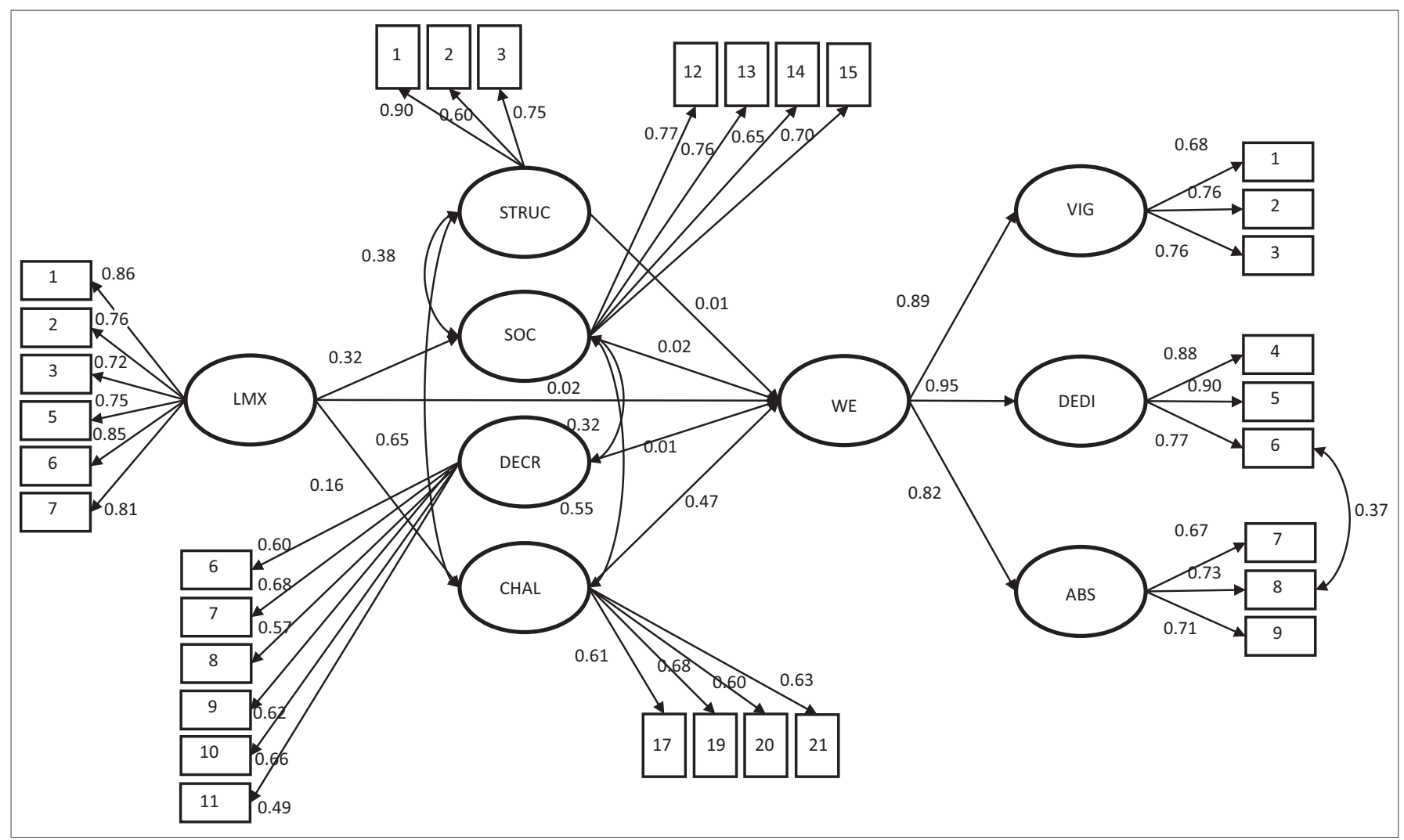

DECR, decreasing hindering job demands; CHAL, increasing challenging job demands; WE, work engagement; VIG, vigour; DEDI, dedication; ABS, absorption; STRUC, increasing structural job resources; SOC, increasing social job resources; LMX, leader-member exchange.

Note: Only significant paths are displayed. Control variables are not displayed.

FIGURE 1: Overview of the structural model.

current job demands and resources to show that job crafting is more than a reactive response to the availability of job resources.

A high-quality relationship with supervisors was not associated with job crafting behaviours aimed at increasing structural job resources. Therefore, increasing structural job resources was no significant mediator in the association between LMX and work engagement. Structural job resources reflect the employees' motivation to develop professionally and originate from 'within' the employee. These internal job resources can be distinguished from external job resources such as job control or social support that originate from 'outside' the person (Deci, Koestner \& Ryan, 1999). The results from our study suggest that a high-quality relationship with supervisors do not necessarily motivate employees to increase internal job resources. Apparently, there is more needed. Autonomy and positive feedback are important factors that increases the employees' motivation to develop from within (Deci et al.,1999; Ryan \& Deci, 2000). Supervisors should provide both this to their employees, especially because our results replicated earlier research in which structural job resources was the strongest predictor of work engagement (Bakker et al., 2012).

The results supported the third hypothesis because increasing challenging job demands was a significant mediator in the association between LMX and work engagement. This result suggests that employees in high-quality relationships with their supervisors create a challenging work environment that develops their knowledge and skills (LePine et al., 2005), which fosters enthusiasm and absorption that are characteristic of work engagement (Bakker et al., 2012). This finding is in line with the two-dimensional work stressor framework (Podsakoff et al., 2007). This model proposes that there are two kinds of demands: hindrance demands and challenge demands. Challenge demands are 'good' demands and are associated positively with motivational outcomes at work. In contrast, hindrance demands are 'bad' demands that may initiate health impairment. Regarding the JD-R model (Bakker \& Demerouti, 2007; Demerouti \& Bakker, 2011; Demerouti et al., 2001), our findings suggest that not all job demands exhaust employees' resources and lead to a depletion of energy. Challenge job demands might even be associated with the motivational process of the JD-R model by promoting personal growth and achievement of the employee.

The fourth hypothesis did not receive support because decreasing hindering job demands was not a significant mediator in the association between LMX and work engagement. Our study showed that a high-quality LMX with a supervisor was not associated with the employees tendency to decrease hindering job demands. Perhaps it is difficult to reduce hindering job demands. Hindering job demands could be perceived as a given and not as an alterable work characteristic (Hakanen, Bakker \& Schaufeli, 2006). Only alterables are easily changed in the short term 
(Cooley \& Yovanoff, 1996). If employees felt able to reduce hindering job demands, they would feel more engaged because our study revealed a positive association between reducing hindering job demands and work engagement. When employees perceive that their demands have become too high, they stay engaged when they proactively lower their job demands (Tims et al., 2012). This suggests that decreasing hindering job demands can increase the optimal level of job challenge. It seems that, even though job crafting has a widely accepted positive role, there is also a 'negative' side of job crafting (Oldham \& Hackman, 2010; Wrzesniewski \& Dutton, 2001).

It is important to note that the effects of LMX and job crafting behaviours on work engagement were small, which resulted in small indirect effects too. These small effects were significant because of the small standard error in our sample. The standard error gives a measure of how well a sample represents the population. When the sample is representative, the standard error will be small (Field, 2013). This means that the effects found in our sample are representative of the effects in the population, and even though the effects were small, they were statistically significant and meaningful.

\section{Limitations and recommendations}

In addition to the contributions of this study to the knowledge of LMX, job crafting and work engagement, limitations of this study should be noted as well. Firstly, the most important limitation is the cross-sectional design of this study. This means that no causal inferences concerning the associations between LMX, job crafting and work engagement can be drawn. It is possible that employees who are more engaged have better relationships with their supervisors because they are more energetic and enthusiastic (Schaufeli et al., 2002), which in turn increases job crafting behaviours. We cannot exclude this possibility even though previous research supported the causality of the generally accepted assumption that work engagement is an outcome of job demands and job resources (Bakker \& Demerouti, 2007; Demerouti \& Bakker, 2011; Demerouti et al., 2001; Hakanen, Perhoniemi \& Toppinen-Tanner, 2008; Schaufeli et al., 2009). Another important limitation of the cross-sectional approach to mediation is the possible generation of biased estimates of longitudinal parameters (Maxwell \& Cole, 2007). The only longitudinal study that examined one of the paths in our theoretical model is the study by Tims et al. (2013). They found a stronger effect of increasing structural job resources on work engagement than in the current study, which suggests that our study underestimated this effect. For future research, the use of longitudinal designs is recommended to examine the causality and the estimates of the hypothesised effects.

The second limitation is the lack of knowledge about the actual supervisors of the employees. Future research could relate quality of relationships rated by the employees to specific supervisors and examine the variance in the quality of relationships per supervisor. The central principle of LMX theory is that supervisors form differential relationships with their subordinates (Bauer \& Green, 1996). The focus on the quality of the relationship distinguishes LMX theory from conceptual overlapping theories such as the transformationaltransactional leadership theory, which focuses on characteristics of the supervisor (Bass, 1991). This theory posits that transactional supervisors get things done by rewarding employees who do well and penalising employees who do not do good work. In contrast, the transformational supervisor is charismatic and inspiring, intellectually stimulates employees and pays high attention to individual differences among employees (Bass, 1991). It has been argued that transformational supervisors build and nourish highquality LMX (Wang, Law, Hackett, Wang \& Chen, 2005). This would mean that some supervisors will have more highquality relationships with their employees than other supervisors. However, according to LMX theory, there still would be a considerable variance in quality of relationships among the subordinates. Future research could examine the quality of relationships between and within supervisors to disentangle LMX theory from transformational-transactional leadership theories.

The third limitation involves the construct validity of the measures used. Even though we used validated measures to examine LMX, job crafting and work engagement, the CFAs revealed that items had to be omitted from the questionnaires measuring LMX and job crafting. Our results showed that measuring LMX with six items is preferred above the original seven-item questionnaire (Liden \& Graen, 1980). Four items with a factor loading $<0.4$ were removed from the job crafting scale. Three of the four items, except item 18, also had the lowest factor loading in the originally developed scale (Tims et al., 2012). Future research should examine the construct validity of the questionnaires used and create shorter questionnaires when necessary.

The fourth limitation concerns the specific sample of highly educated employees working for a mail and parcels company. This raises the question to what extent the results can be generalised to other populations with, for instance, lower education levels, especially because education level has been argued to be positively correlated with opportunities for job crafting (Tims et al., 2012). It is important to note that education level was controlled for in the data analysis. Because our sample was relatively heterogeneous with employees working for different departments with different professions, we believe that our main findings are not unique to this sample. Still, it would be interesting for future research to employ samples from other contexts to broaden the knowledge about LMX, job crafting and work engagement.

\section{Conclusion and practical implications}

Findings from this study suggest a crucial role for supervisors in fostering work engagement. Supervisors who support subordinates and give them direction and information increase willingness among subordinates to dedicate efforts, go beyond job descriptions, take a self-starting approach to 
work and alter their jobs in accordance with their own preferences, values and skills. The increased fit between job characteristics and the characteristics of the employee increase absorption in one's work, concentration, attentiveness, enthusiasm and involvement. It increases work engagement.

These findings show that supervisors have unique opportunities to positively influence employee behaviour. Supervisors could be more effective when they are aware of the importance of employees' reciprocity expectations and the relational requirements of a high-quality relationship, such as personal development and social bounding (Wang et al., 2005). The quality of exchanges between supervisors and employees could be improved through training of the supervisors. Research has shown that the quality of the relationship between supervisor and employee increases when supervisors trained their active listening skills and exchanged mutual expectations and resources with their employees (Graen, Novak \& Sommerkamp, 1982). It is also important that supervisors give their employees autonomy and positive feedback. Research suggests that positive feedback and autonomy enhance the motivation of the employee to develop from 'within' (Deci et al., 1999; Ryan \& Deci, 2000). Autonomy is also a necessary precondition for job crafting to take place (Leana, Appelbaum \& Shevchuk, 2009; Petrou et al., 2012) and an important predictor of work engagement (Demerouti \& Bakker, 2011). In sum, supervisors who are capable of building high-quality relationships with their employees and who are aware of the importance of employee bounding, positive feedback and autonomy have the possibility to increase job crafting behaviours and foster work engagement.

\section{Acknowledgements Competing interests}

The authors declare that they have no competing interests which may inappropriately influence their contribution to this article.

\section{Authors' contributions}

M.R. was responsible for the study design, analysed the data and wrote the article. A.H. was also responsible for the study design and collected data.

\section{References}

Agarwal, U.A., Datta, S., Blake-Beard, S., \& Bhargava, S. (2012). Linking LMX, innovative behaviour, and turnover intentions: The mediating role of work engagement. Career Development International, 9, 208-230. https://doi.org/10.1108/1362043 1211241063

Allesandri, G., Borgogni, L., Schaufeli, W.B., Caprara, G.V., \& Consiglio, C. (2015). From positive orientation to job performance: The role of work engagement and selfefficacy beliefs. Journal of Happiness Studies, 16, 767-788. https://doi. org/10.1007/s10902-014-9533-4

Anderson, J.C., \& Gerbing, D.W. (1988). Structural equation modeling in practice: A review and recommended two-step approach. Psychological Bulletin, 103, 411423. https://doi.org/10.1037/0033-2909.103.3.411

Babcock-Roberson, M.E., \& Strickland, O.J. (2010). The relationship between charismatic leadership, work engagement, and organizational citizenship behaviors. The Journal of Psychology, 144, 313-326. https://doi.org/10.1080/ 00223981003648336

Bakker, A.B., \& Demerouti, E. (2007). The job-demands resources model: State of the art. Journal of Managerial Psychology, 22, 309-328. https://doi.org/10.1108/ 02683940710733115
Bakker, A.B, Rodríguez-Muñoz, A., \& Sans Vergel, A.I. (2016). Modelling job crafting behaviours: Implications for work engagement. Human Relations, 69, 169-189. https://doi.org/10.1177/0018726715581690

Bakker, A.B., Schaufeli, W.B., Leiter, M.P., \& Taris, T.W. (2008). Work engagement: An emerging concept in occupational health psychology. Work \& Stress, 22, 187-200. https://doi.org/10.1080/02678370802393649

Bakker, A.B., Tims, M., \& Derks, D. (2012). Proactive personality and performance: The role of job crafting and work engagement. Human Relations, 65, 1359-1378. https://doi.org/10.1177/0018726712453471

Bass, B.M. (1991). From transactional to transformational leadership: Learning to share the vision. Organizational Dynamics, 18, 19-31. https://doi. org/10.1016/0090-2616(90)90061-S

Bauer, T.N., \& Green, S.G. (1996). Development of leader-member exchange: A longitudinal test. Academy of Management Journal, 39, 1538-1567. https://doi. org/10.2307/257068

Bhal, K.T., Gulati, N., \& Ansari, M.A. (2009). Leader-member exchange and subordinate outcomes: Test of a mediation model. Leadership \& Organization Development Journal, 30, 106-125. https://doi.org/10.1108/01437730910935729

Breevaart, K., Bakker, A.B., Demerouti, E., \& van den Heuvel, M. (2015). Leadermember exchange, work engagement, and job performance. Journal of member exchange, work engagement, and job performance. Journal of 0088

Browne, M.W., \& Cudeck, R. (1989). Single sample cross-validation indices for covariance structures. Multivariate Behavioral Research, 24, 445-455. https:// doi.org/10.1207/s15327906mbr2404_4

Carmeli, A., Brueller, D., \& Dutton, J.E. (2009). Learning behaviours in the workplace: The role of high-quality interpersonal relationships and psychological safety. Systems Research and Behavioral Science, 26, 81-98. https://doi.org/10.1002/ sres.932

Christian, M.S., Garza, A.S., \& Slaughter, J.E. (2011). Work engagement: A quantitative review and test of its relations with task and contextual performance. Personnel Psychology, 64, 89-136. https://doi.org/10.1111/j.1744-6570.2010.01203.x

Cooley, E., \& Yovanoff, P. (1996). Supporting professionals-at-risk: Evaluating interventions to reduce burnout and improve retention of special educators. Exceptional Children, 62, 336-355. https://doi.org/10.1177/0014402 99606200404

Crawford, E.R., LePine, J.A., \& Rich, B.L. (2010). Linking job demands and resources to employee engagement and burnout: A theoretical extension and meta-analytic test. Journal of Applied Psychology, 95, 834-848. https://doi.org/10.1037/ a0019364

Csikszentmihalyi, M. (1990). Flow: The psychology of optimal experience. New York: Harper.

De Beer, L.T., Tims, M. \& Bakker, A.B. (2016). Job crafting and its impact on work engagement and job satisfaction in mining and manufacturing. South African Journal of Economic and Management Sciences, 19, 400-412. https://doi. Journal of Economic and Manag
org/10.4102/sajems.v19i3.1481

Deci, E.L., Koestner, R., \& Ryan, R.M. (1999). A meta-analytic review of experiments examining the effects of extrinsic rewards on intrinsic motivation. Psychological Bulletin, 125, 627-668. https://doi.org/10.1037/0033-2909.125.6.627

Demerouti, E., \& Bakker, A.B. (2011). The job-demands resources model: Challenges for future research. South African Journal of Industrial Psychology, 37, 1-9. https://doi.org/10.4102/sajip.v37i2.974

Demerouti, E., Bakker, A.B., Nachreiner, F., \& Schaufeli, W.B. (2001). The job demandsresources model of burnout. Journal of Applied Psychology, 86, 499-512. https:// doi.org/10.1037/0021-9010.86.3.499

Dulebohn, J.H., Bommer, W.H., Liden, R.C., Brouer, R.L., \& Ferris, G.R. (2012). A metaanalysis of antecedents and consequences of leader-member exchange: Integrating the past with an eye toward the future. Journal of Management, 38 , 1715-1759. https://doi.org/10.1177/0149206311415280

Dunn, T.J., Baguley, T., \& Brunsden, V. (2014). From alpha to omega: A practical solution to the pervasive problem of internal consistency estimation. British Journal of Psychology, 105, 399-412. https://doi.org/10.1111/bjop.12046

Edmondson, A. (1999). Psychological safety and learning behavior in work teams. Administrative Science Quarterly, 44, 350-383. https://doi.org/10.2307/2666999

Epitropaki, O., \& Martin, R. (2005). From ideal to real: A longitudinal study of the role of implicit leadership theories on leader-member exchanges and employee outcomes. Journal of Applied Psychology, 90, 659-676. https://doi. org/10.1037/0021-9010.90.4.659

Field, A. (2013). Discovering statistics using IBM SPSS statistics (4th ed.). London: Sage.

Fouché, E., Rothmann, S.S., \& van der Vyver, C. (2017). Antecedents and outcomes of meaningful work among school teachers. South African Journal of Industrial Psychology, 43, 1-10. https://doi.org/10.4102/sajip.v43i0.1398

Gerstner, C.R., \& Day, D.V. (1997). Meta-analytic review of leader-member exchange theory: Correlates and construct issues. Journal of Applied Psychology, 82, 827844. https://doi.org/10.1037/0021-9010.82.6.827

Giallonardo, L.M., Wong, C.A., \& Iwasiw, C.L. (2010). Authentic leadership of preceptors: Predictor of new graduate nurses' work engagement and job satisfaction. Journal of Nursing Management, 18, 993-1003. https://doi. org/10.1111/j.1365-2834.2010.01126.x

Gouldner, A.W. (1960). The norm of reciprocity: A preliminary statement. American Sociological Review, 25, 161-177. https://doi.org/10.2307/2092623

Graen, G., Novak, M.A., \& Sommerkamp, P. (1982). The effects of leader-member exchange and job design on productivity and satisfaction: Testing a dual 
attachment model. Organizational Behavior and Human Performance, 30, 109131. https://doi.org/10.1016/0030-5073(82)90236-7

Graen, G.B., \& Uhl-Bien, M. (1995). Relationship-based approach to leadership: Development of leader-member-exchange (LMX) theory of leadership over 25 years: Applying a multi-level multi-domain perspective. Leadership Quarterly, 6, 219-247. https://doi.org/10.1016/1048-9843(95)90036-5

Gu, Q., Tang, T.L.P., \& Jiang, W. (2015). Does moral leadership enhance employee creativity? Employee identification with leader and leader-member exchange (LMX) in the Chinese context. Journal of Business Ethics, 126, 513-529. https:// doi.org/10.1007/s10551-013-1967-9

Hakanen, J.J., Bakker, A.B., \& Schaufeli, W.B. (2006). Burnout and work engagement among teachers. Journal of School Psychology, 43, 495-513. https://doi. org/10.1016/j.jsp.2005.11.001

Hakanen, J.J., Perhoniemi, R., \& Toppinen-Tanner, S. (2008). Positive gain spirals at work: From job resources to work engagement, personal initiative and work-unit innovativeness. Journal of Vocational Behavior, 72, 78-91. https://doi. org/10.1016/j.jvb.2008.01.003

Halbesleben, J.R.B. (2010). A meta-analysis of work engagement: Relationships with burnout, demands, resources and consequences. In A.B. Bakker \& M.P. Leite (Eds.), Work engagement: Recent developments in theory and research (pp. 102117). New York: Psychology Press.

Harter, J.K., Schmidt, F.L., \& Hayes, T.L. (2002). Business-unit-level relationship between employee satisfaction, employee engagement, and business outcomes: A meta-analysis. Journal of Applied Psychology, 87, 268-279. https://doi. org/10.1037/0021-9010.87.2.268

Hobfoll, S.E. (1989) Conservation of resources: A new attempt at conceptualizing stress. American Psychologist, 44, 513-524. https://doi.org/10.1037/0003066X.44.3.513

Hu, L.T., \& Bentler, P.M. (1999). Cutoff criteria for fit indexes in covariance structure analysis: Conventional criteria versus new alternatives. Structural Equation Modeling: A Multidisciplinary Journal, 6, 1-55. https://doi.org/10.1080/107055 19909540118

Ilies, R., Nahrgang, J.D., \& Morgeson, F.P. (2007). Leader-member exchange and citizenship behaviors: A meta-analysis. Journal of Applied Psychology, 92, 269-277. https://doi.org/10.1037/0021-9010.92.1.269

Jackson, L.T., Rothmann, S., \& Van de Vijver, F.J. (2006). A model of work-related wellbeing for educators in South Africa. Stress and Health, 22, 263-274. https://doi. org/10.1002/smi.1098

Jacobs, S., Renard, M., \& Snelgar, R.J. (2014). Intrinsic rewards and work engagement in the South African retail industry. South African Journal of Industrial Psychology, 40, 1-13. https://doi.org/10.4102/sajip.v40i2.1195

Kahn, W.A. (1990). Psychological conditions of personal engagement and disengagement at work. Academy of Management Journal, 33, 692-724. https:// doi.org/10.2307/256287

Kanfer, R. (1990). Motivation and individual differences in learning: An integration of developmental, differential and cognitive perspectives. Learning and Individual Differences, 2, 221-239. https://doi.org/10.1016/1041-6080(90) 90023-A

Kline, R.B. (2005). Principles and practice of structural equation modeling. New York: Guilford Press.

Leana, C., Appelbaum, E., \& Shevchuk, I. (2009). Work process and quality of care in early childhood education: The role of job crafting. Academy of Management Journal, 52, 1169-1192. https://doi.org/10.5465/AMJ.2009.47084651

LePine, J.A., Podsakoff, N.P., \& LePine, M.A. (2005). A meta-analytic test of the challenge stressor-hindrance stressor framework: An explanation for inconsistent relationships among stressors and performance. Academy of Management Journal, 48, 764-775. https://doi.org/10.5465/AMJ.2005.18803921

Li, X., Sanders, K., \& Frenkel, S. (2012). How leader-member exchange, work engagement and HRM consistency explain Chinese luxury hotel employees' job performance. International Journal of Hospitality Management, 31, 1059-1066. https://doi.org/10.1016/j.ijhm.2012.01.002

Liden, R., \& Graen, G. (1980). Generalizability of the vertical dyad linkage model of leadership. Academy of Management Journal, 23, 451-465. https://doi. org/10.2307/255511

Liden, R.C., Sparrowe, R.T., \& Wayne, S.J. (1997). Leader-member exchange theory: The past and potential for the future. In G.R. Ferris (Ed.), Research in personnel and human resources management (pp. 47-119). Greenwich: JAI.

Liden, R.C., Wayne, S.J., \& Stilwell, D. (1993). A longitudinal study on the early development of leader-member exchanges. Journal of Applied Psychology, 78, 662-674. https://doi.org/10.1037/0021-9010.78.4.662

Macey, W.H., \& Schneider, B. (2008). The meaning of employee engagement. Industrial and Organizational Psychology, 1, 3-30. https://doi.org/10.1111/j.17549434.2007.0002.x

Marsh, H.W., Hau, K.T., \& Wen, Z. (2004). In search of golden rules: Comment on hypothesis-testing approaches to setting cutoff values for fit indexes and dangers in overgeneralizing $\mathrm{Hu}$ and Bentler's (1999) findings. Structural Equation Modeling, 11, 320-341. https://doi.org/10.1207/s15328007sem1103_2

Martin, R., Guillaume, Y., Thomas, G., Lee, A., \& Epitropaki, O. (2016). Leader-Membe exchange (LMX) and performance: A meta-analytic review. Personnel Psychology, 69, 67-121. https://doi.org/10.1111/peps.12100
Maxwell, S.E., \& Cole, D.A. (2007). Bias in cross-sectional analyses of longitudinal mediation. Psychological Methods, 12, 23-44. https://doi.org/10.1037/1082989X.12.1.23

May, D.R., Gilson, R.L., \& Harter, L.M. (2004). The psychological conditions of meaningfulness, safety and availability and the engagement of the human spirit at work. Journal of Occupational and Organizational Psychology, 77, 11-37. https:// work. Journal of Occupational and Orga

Mauno, S., Kinnunnen, U., \& Ruokolainen, M. (2007). Job demands and resources as antecedents of work engagement: A longitudinal study. Journal of Vocational Behavior, 70, 149-171. https://doi.org/10.1016/j.jvb.2006.09.002

Morrow, P., Suzuki, Y., Crum, M., Ruben, R., \& Pautsch, G. (2005). The role of leader-member-exchange in high turnover work environments. Journal of Managerial Psychology, 20, 681-695. https://doi.org/10.1108/0268394 0510631444

Muthén, L.K. \& Muthén, B.O. (2012). Mplus user's guide (7th ed.). Los Angeles, CA: Muthén \& Muthén.

Ndlouvu, N., \& Parumasur, S.B. (2005). The perceived impact of downsizing and organisational transformation on survivors. South African Journal of Industrial Psychology, 31, 14-21. https://doi.org/10.4102/sajip.v31i2.198

Nord, W.B. (1969). Social exchange theory: An integrative approach to socia conformity. Psychological Bulletin, 71, 174-208. https://doi.org/10.1037/ h0027032

Oldham, G.R., \& Hackman, J.R. (2010). Not what it was and not what it will be: The future of job design research. Journal of Organizational Behavior, 31, 463-479. https://doi.org/10.1002/job.678

Olivier, A.L., \& Rothmann, S. (2007). Antecedents of work engagement in a multinational company. South African Journal of Industrial Psychology, 33, 49-56. https://doi.org/10.4102/sajip.v33i3.396

Pearl, J. (2009). Causal inference in statistics: An overview. Statistics Surveys, 3, 96146. https://doi.org/10.1214/09-SS057

Petrou, P., Demerouti, E., Peeters, M.C.W., Schaufeli, W.B., \& Hetland, J. (2012). Crafting a job on a daily basis: Contextual correlates and the link to work engagement. Journal of Organizational Behavior, 33, 1120-1141. https://doi. engagement. Journal
org/10.1002/job.1783

Podsakoff, N.P., LePine, J.A., \& LePine, M.A. (2007). Differential challenge stressorhindrance stressor relationships with job attitudes, turnover intentions, turnover and withdrawal behavior: A meta-analysis. Journal of Applied Psychology, 92, 438-454. https://doi.org/10.1037/0021-9010.92.2.438

Rich, B.L., LePine, J.A., \& Crawford, E.R. (2010). Job engagement: Antecedents and effects on job performance. Academy of Management Journal, 53, 617-635. https://doi.org/10.5465/AMJ.2010.51468988

Rothmann, S. (2008). Job satisfaction, occupational stress, burnout and work engagement as components of work-related wellbeing. South African Journal of Industrial Psychology, 34, 11-16. https://doi.org/10.4102/sajip.v34i3.424

Rothmann, S., \& Joubert, J.H.M. (2007). Job demands, job resources, burnout and work engagement of managers at a platinum mine in the North West Province. South African Journal of Business Management, 38, 49-61.

Ryan, R.M., \& Deci, E.L. (2000). Self-determination theory and the facilitation of intrinsic motivation, social development, and well-being. American Psychologist, 55, 68-78. https://doi.org/10.1037/0003-066X.55.1.68

Salanova, M., \& Schaufeli, W.B. (2008). A cross-national study of work engagement as a mediator between job resources and proactive behaviour. The Internationa Journal of Human Resource Management, 19, 116-131. https://doi. org/10.1080/09585190701763982

Schaufeli, W.B., Bakker, A.B., \& Salanova, M. (2006). The measurement of work engagement with a short questionnaire: A cross-national study. Educational and
Psychological Measurement, 66, 701-716. https://doi.org/10.1177/0013164 Psychological

Schaufeli, W.B., Bakker, A.B., \& van Rhenen, W. (2009). How changes in job demands and resources predicts burnout, work engagement, and sickness absenteeism. and resources predicts burnout, work engagement, and sickness absenteeism.
Journal of Organizational Behavior, 30, 893-917. https://doi.org/10.1002/ journal

Schaufeli, W.B., Salanova, M., González-Romá, V., \& Bakker, A.B. (2002). The measurement of engagement and burnout: $\mathrm{A}$ two sample confirmatory factor analytic approach. Journal of Happiness Studies, 3, 71-92. https://doi. org/10.1023/A:1015630930326

Seppäla, P., Mauno, S., Kinnunen, M.-L., Feldt, T., Juuti, T., Tolvanen, A., et al. (2012). Is work engagement related to healthy cardiac autonomic activity? Evidence from a field study among Finnish women workers. The Journal of Positive Psychology, 7 95-106. https://doi.org/10.1080/17439760.2011.637342

Sonnentag, S., Mojza, E.J., Binnewies, C., \& Scholl, A. (2008). Being engaged at work and detached at home: A week-level study on work engagement, psychological detachment, and affect. Work \& Stress, 22, 257-276. https://doi. org/10.1080/02678370802379440

Sparrowe, R.T., \& Liden, R.C. (1997). Process and structure in leader-member exchange. Academy of Management Review, 22, 533-552.

Stander, M.W., \& Rothmann, S. (2010). Psychological empowerment, job insecurity and employee engagement. South African Journal of Industrial Psychology, 36, 1-8. https://doi.org/10.4102/sajip.v36i1.849

Stevens, J.P. (2002). Applied multivariate statistics for the social sciences. Hillsdale: Erlbaum.

Tims, M., \& Bakker, A.B. (2010). Job crafting: Towards a new model of individual job redesign. South African Journal of Industrial Psychology, 30, 1-9. https://doi. org/10.4102/sajip.v36i2.841 
Tims, M., Bakker, A.B., \& Derks, D. (2012). Development and validation of the job crafting scale. Journal of Vocational Behavior, 80, 173-186. https://doi. org/10.1016/j.jvb.2011.05.009

Tims, M., Bakker, A.B., \& Derks, D. (2013). The impact of job crafting on job demands, job resources, and well-being. Journal of Occupational Health Psychology, 18, 230-240

Wang, H., Law, K.S., Hackett, R.D., Wang, D., \& Chen, Z.C. (2005). Leader-member exchange as a mediator of the relationship between transformational leadership and followers' performance and organizational citizenship behavior. Academy of Management Journal, 48, 420-432.

Willemse, M., \& Deacon, E. (2015). Experiencing a sense of calling: The influence of meaningful work on teachers' work attitudes. South African Journal of Industrial Psychology, 41, 1-9. https://doi.org/10.4102/sajip.v41i1.1274

Wrzesniewski, A., \& Dutton, J.E. (2001). Crafting a job: Revisioning employees as active crafters of their job. Academy of Management Review, 26, 179-201. 